\title{
Export Competitiveness of Indian Oilseeds: The Method of Constant Market Share (CMS) with Special Reference to Groundnut
}

\author{
Anudeep Arora, Durgesh Batra
}

\begin{abstract}
This research Paper examines the export competiveness of oilseeds. The main and huge production in agriculture is oilseeds which make India on the first number in Production of oilseeds in the world. Oilseeds compose one of the significant groups of cash crops in Indian agriculture. India has a proportional benefit in agriculture and there is a considerable potential in raising farm returns and employment by stepping up agro base exports. The constant market share (CONSTANT MARKET SHARE) study framework is used to decompose changes in India's share of the worldwide market for goods export in to competitiveness and structural consequence over 2001-2017. The CONSTANT MARKET SHARE Method is universally used to observe empirically the country's export performance. This paper is addressed to examine the regions export performance by applying CONSTANT MARKET SHARE Method.
\end{abstract}

Index Terms: CONSTANT MARKET SHARE, Export, Export Competitiveness, Trade Specialization, Groundnut, Oilseed, Export Potential.

\section{INTRODUCTION}

For economic strength of entire world it is essential that international trade grows. The growth of international trade is directly related to import and export. Two biggest challenges of international trade is sudden change of policies and unawareness of trade rules of particular country. There was a necessity of a global body that can provide international traders confidence to trade across the planet.[5] Until 1991 the trade in agriculture was heavily controlled by government interventions, namely tariff and non-tariff barriers, quantitative restrictions, licensing and canalization and subsidies. Economic reforms in the early 1990s followed by establishment of WORLD TRADE ORGANIZATION in 1995 changed agricultural trade rapidly.[6] Trade liberalization led to greater integration of world economies. It opened up new opportunities, challenges and competition in agricultural markets (Jagdambe 2016). Studies shows mixed effect of liberalisation on Indian agricultural trade (Bhalla 2004; Karnool et al. 2007; Angles et al. 2011; Sharma 2013). In order to boost agriculture exports it becomes indispensable to assess the competitiveness of agricultural exports. We couldn't come across any study that

Revised Manuscript Received on July 02, 2019.

Anudeep Arora, Assistant Professor, Kamal Institute of Higher Education and Advance Technology,Affilated to IP university, New Delhi, India

Dr.Durgesh Batra, Associate Professor Amity University Jaipur, India focuses on competitiveness of groundnut from India other than Rani et al.

(2014). Therefore, competitiveness of Indian groundnut in post- WORLD TRADE ORGANIZATION period is crucial to analyse its sustainability in domestic and international markets. This study has made a modest attempt to analyse competitiveness of India's groundnut export using CONSTANT MARKET SHARE approach.

Oilseeds constitute one of the important groups of cash crops in Indian agriculture. They are the most important sources of supply of edible oils in the country. Indian vegetable oil economy is the fourth largest in the world, next only to that of USA, China and Brazil, accounting for about 14 per cent of world oilseed area and 7 per cent of global production. However, the productivity in India is low, only $986 \mathrm{~kg} / \mathrm{ha}$ (2003) as compared to the world average of $1777 \mathrm{~kg} / \mathrm{ha}$ (2003).[6] The oilseed sector has been playing a major role in reducing the gap in domestic demand and supply, and is also earning valuable foreign exchange from its byproducts (Virupakshappa and Kiresur, 1998). The oilseed scenario in the country has undergone a sea change during the past twenty years. [14] India emerged as a net exporter of edible oil in 1990s from a net importer during the early 1980s. However, it has again become a net importer, accounting for more than 40 per cent of annual edible oil needs. India has a comparative advantage in agriculture, and there is a considerable potential in raising farm income and employment by stepping up agro-based exports. Economic integration and trade liberalization will have a great impact on the national economy in general, and on the agricultural sector in particular. It will be a good opportunity to expand markets and acquire advanced technologies from the developed countries.[16]

\section{REVIEW OF LITERATURE}

Samar Verma (November, 2002) researched and take a deep dig into "Export Competitiveness of Indian Textile and Garment Industry" massively where he originate the competitiveness is expanding day by day in coming era for all the firms including clothes and textiles. Indian textile and clothing industry takes a considerable place in Indian economy which contributes about $4 \%$ of GDP and $14 \%$ of industrial output. This is the second largest employer after agriculture. It reveals that agriculture is the first largest containing employer. This study has also clarified \& 
examined the India's competitive performance in two international EU and US markets for (ATC) product categories which all are important for Indian export. He also found the Indian exports to the US and EU are the whole export competitive. It has also delineated the changing landscape in the international trading environment which is likely to be extensively get a impact on global textile and clothing trade.

Widgren (2005) on the comparative benefit of a sample of Asian, American and European countries from 1996 to 2002. His probe is into mostly used the data of HS classification at the 4-digit level. He studied the source of comparative advantage and came to the following conclusion. In the context of the Asian continent, the factor content of comparative advantage had some kind of similarity. Whereas in the case of the US, it was basically based on highly expert labour and for the EU, it moved towards use of human as well as physical capital.

Ranjana Kumar (2005) reported in his worked that "Constrains facing Indian agriculture: Need for policy intervention" India continues to be predominantly an agrarian economy and without improvements and development in this sector, the economy as a whole cannot anticipate achieving and maintaining a balanced and sustainable development trend.

RS Deshpande (March, 2005) has researched that after the review in Karnataka, he come across with looking at the economy factor of Karnataka state all over peers it entirely depends upon the agriculture. The mostly part of the Karnataka is enclosed by the agriculture. Karnataka is also having mostly poor population which is located in rural areas among the agriculture laborers this shows that most of the poor population do the agriculture which makes the Karnataka strong in their back bone because Karnataka state is having the large production of agriculture and hence for increasing their motherland export market recently Karnataka emergence as an important partner in boosting up the export growth of the country. Among all other states in the production Karnataka comes on a medium level.

HailegiorgisBiramoAllaro (2011) researched on "Export Performance of Oilseeds and ITS Determinants in Ethiopia"than he found the export presentation of the oilseed over the period 1974 - 2009. The Ethiopia country still depends upon the few product of agriculture. This research also examines the coefficients of real output and nominal exchange. In Ethiopia technology were applied for agriculture production. This theory studies over the last half of 18th century when Adam Smith realized the significance of specialization. Ethiopia also do the trade of oilseed over the world. Ethiopia exports the oilseeds in world market. He also explained the major oil seeds worldwide are: Soybean, rapeseed, cottonseed, safflower seed, groundnut, palm, copra, Sesame, Castro seed, maize oil and coconut oil. The major producers of oilseeds are India, China, US, Europe, Canada and Brazil. All these countries have the large production of oilseed across the world. Ethiopia is only $500 \mathrm{~m}$ above from the sea level so Ethiopia has a very different climate so the production of oilseed in Ethiopia is very less.
Oilseed is only the one crop which is second largest earner for the country in agriculture trade.

Shoufeng et.al (2011) analyses the export competitiveness of agricultural products between China and Central Asian countries by using the RCA index and trade competitiveness index, came to the following conclusions: (1) China's total agriculture products do not have comparative advantage while Central Asian countries have changed from comparative advantage into comparative 4 disadvantage, (2) The total agri-products of both China and Central Asian countries have changed from trade competitive advantage to trade competitive disadvantage, (3) China and Central Asian countries have different advantage structures on specific categories of agricultural products, which presents vast bilateral trade potential on the basis of comparative advantage.

Dr. N C Pahariya (2014) researched on "Impact Assessment of Trade Liberalisation in Oilseeds Sector: Rajasthan" than he originated and came up with that India followed different types of oilseed policies until 1994 which gave different types of benefits in oilseed sector. It means all the policies followed for oilseed they all are followed before establishing the WORLD TRADE ORGANIZATION agreement on oilseed in 1995. These all policies was not only able to double the oilseed output and stabilize the oilseed production but these also use to production of new crops like soybean, sunflower etc. even for those areas where poor farmers typically face more limited growth opportunities. In 1990's India was more self sufficient in edible oils and a large exporter in oilseeds. This represent that India is always a large exporter in oilseeds which represent India always has good creation of oilseeds this make India unique and put India among those countries who have large market share of oilseed in world market. In the mid of 1990's cheaper imports and faster economic growth accelerates the demand of edible oils which was imported sufficiently according to the demand. The trade liberalization in oilseed sector initiated in 1994-45.

$\begin{array}{lll}\text { DushyantKumar(Feb,2015) researched on } & \text { "EXPORT } \\ \text { COMPETITIVENESS OF INDIAN } & \text { TEXTILE }\end{array}$ INDUSTRY" and subsequently he followed that sectoral structure of world trade and country condition in competitiveness reflect in its export performance. Whereas Dushyant Kumar imply those methods which is constant market share (CONSTANT MARKET SHARE) to analyze the constant measures in variations market share found that the geographical structure of exports. Dushyant Kumar essentially analyzes the export performance and export competitiveness from 2010 to 2013. He created and come across with both export performance and export competitiveness more than three years and groping in depth for both export performance competitiveness he applied Balassa (1965) formula where he get a hold on Revealed Comparative Advantage (RCA) which represent the competitiveness of the country, which lead into measuring the method for export presentation and

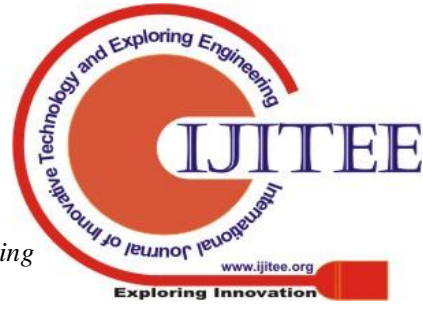


export competitiveness all the required data occupied from Indian Trade Center (ITC) which is used as source of statistics.

Sunil Kumar Niranjan (2016) whereas he researched and after the study on WORLD TRADE ORGANIZATION agreements in India that the WORLD TRADE ORGANIZATION agreement and other previous agreement like GATT they all put a great impact on all different sectors of the India either it is industry or any trading business but the major effect of this agreement is on agriculture of India because Indian economy is mainly depend upon the agriculture if the trade of agriculture increase than Indian economy increase also. Here Sunil Kumar Niranjan also did some researches on the way of imports and exports he find out and come across that how do India agriculture trade in and sell overseas what are their level of creative ideas and outline to promote import and export since 1995 and he also analyze the trend of export and imports since 1995 of the India. Here he mainly illustrate \& explain the agriculture trade after establishing the WORLD TRADE ORGANIZATION. It reveals that WORLD TRADE ORGANIZATION is the successor over the GATT. There were 77 countries member when WORLD TRADE ORGANIZATION established on 1 Jan 1995 and there are 154 countries have member of WORLD TRADE ORGANIZATION by 2011. Leading aim and principles of WORLD TRADE ORGANIZATION was to enlarge the economic factor for the trade in goods and services to increase the living standard of member countries still Indian trade did not add on or put any effort to enhance enough as much we expected and neither had we seen any change in the living standard of India.

Girish Kumar Gupta and Mohd.Asif Khan (2017) take a deep dig into it and scrutinize on "Exports Competitiveness of the Indian Textile Industry throughout and after ATC" later than he started and initiate with the level of the output productivity of the country by calculating the export competitiveness. Here he make clear and enlighten the way to calculate the export competitiveness. He also enlighten \& examines the International market share, Revealed Comparative Advantage (RCA), Compound Annual Growth Rate (CAGR) and Coefficient variation. In favor of considering all these results all the data occupied from International Trade Center (ITC). He also examined that the country is growing on the rise in the production of textiles. It also examines comparative analysis. If we see according to the \% share point of view than India and China are the most competitive country but Brazil did not get better to progress its position after ATC.

\section{OBJECTIVES}

1. To examine the export performance of Indian oilseeds.

2. To analysis the competitiveness of Indian oilseed for period of 2001 to 2017.

\section{RESEARCH METHODOLOGY}

To achieve the objectives of the paper the study employs two economic methodologies. Firstly it uses various Revealed
Comparative Advantage's and then CONSTANT MARKET SHARE (Constant Market Share).

Measures of revealed comparative advantage (RCA) have been used to help assess a country's export potential. The RCA indicates whether a country is in the process of extending the products in which it has a trade potential, as opposed to situations in which the number of products that can be competitively exported is static. [1][2]

Balassa - RCA Index

Bela Balassa introduced the revealed comparative index to measure the comparative advantage of any country. According to Balassa $(1979,1986,1989)$ when the factor costs related data are not available, comparative advantage of a country can be revealed with the help of relative costs and differences in various factors other than price as indicated by pattern of exports. Balassa's Revealed Comparative Advantage (RCA) Index known as Balassa Index is more likely an index of revealed export advantage (RXA) [1]

The RCA index of country I for product $\mathrm{j}$ is often measured by the product's share in the country's exports in relation to its share in world trade:

RCAij $=\mathrm{RXA}=(\mathrm{xij} / \mathrm{Xit}) /(\mathrm{xwj} / \mathrm{Xwt})$

(1)

Where xij and xwj are the values of country i's exports of product $\mathrm{j}$ and world exports of product $\mathrm{j}$ and where Xit and Xwt refer to the country's total exports and world total exports. A value of less than unity implies that the country has a revealed comparative disadvantage in the product. Similarly, if the index exceeds unity, the country is said to have a revealed comparative advantage in the product.

Vollrath- Alternative RCA Indices

One major censure has been identified in Balassa's RCA is the oversight of imports; this index reveals only export advantage of nation rather than the comparative advantage. In 1991, Thomas Lachlan Vollrath has proposed three alternative RCA indices to measure the revealed comparative advantage of nation. The first, the relative trade advantage (RTA) is can be expressed as:

$R_{C A}=R T A=R X A-R M A=\frac{\frac{X i j}{X w i j}}{\frac{X i}{X w}}-\frac{\frac{M i j}{M w j}}{\left(\frac{M i}{M w}\right)}$

Here all variables are same as in RCA expect $M$ represents imports.

The second measure is the logarithm of the relative export advantage (ln RXA ) is expressed as:

$\mathrm{RCA}_{\mathrm{ij}}=\ln \mathrm{RXA}=\ln \{(\mathrm{Xij} / \mathrm{Xit}) /(\mathrm{Xwj} / \mathrm{Xwt})\}$

The third Vollrath measure is revealed competitiveness (RC) can be defined as:

$\mathrm{RCA}_{\mathrm{ij}}=\ln \mathrm{RXA}-\ln \mathrm{RMA}=\ln \left(\frac{\mathrm{Xij}_{\mathrm{Xwj}}}{\mathrm{Xi}_{\mathrm{W}}}\right)-\ln \left(\frac{\mathrm{Mij}}{\mathrm{Mwj}}\left(\frac{\mathrm{Mi}}{\mathrm{Mw}}\right)\right)$

If the values of all three of Vollrath's measures are positive it shows a competitive advantage of country in that product while negative values imply comparative/competitive disadvantage of country in that product. 


\section{CONSTANT MARKET SHARE (CMS)}

Constant Market Share method decomposes the export growth to provide a better understanding of whether this growth is coming from increased competitiveness or resulting from various other structural factors. Constant Market Share (CMS) technique facilitates to comprehend about export performance of a selected country or group of countries vis-à-vis to their competitors in choosing fast growing markets (product or destination or sectors).

According to the CMS model the export growth of concern country can attribute to structural or competitive factors as below:

- Structural Effects or Demand Effects

a. General Rise in World's Demand/Import

b. Product/Commodity Composition Effects

c. Market Distribution Effects

- Competitivness Effects

The four key components of CONSTANT MARKET SHARE model which play a vital role in country's export performance are World Trade Effect (WTE); Commodity Composition Effects (CCE); Market Distribution Effects (MDE) and Competitiveness Effects (CE).

The CONSTANT MARKET SHARE model, as applied in this study, can be numerically presented as:

$$
\begin{gathered}
\Delta q=\left[\sum_{i=1}^{n} r q_{i}^{0}\right]+\left[\sum_{i=1}^{n} r_{i} q_{i}^{0}-r q_{i}^{0}\right]+\left[\sum_{i=1}^{n} \sum_{j=1}^{m} r_{i j} q_{i j}^{0}-\sum_{i=1}^{n} r_{i} q_{i}^{0}\right] \\
+\left\lceil\sum_{i=1}^{n} q_{i}^{1}-q_{i}^{0}-\sum_{i=1}^{n} \sum_{j=1}^{m} r_{i j} q_{i j}^{0}\right]
\end{gathered}
$$

Here, Superscript 1 and 0

$1=$ Terminal time period

$0=$ Initial time period

$\mathrm{i}=1,2 \ldots \ldots \mathrm{n}=$ Number of commodities

$\mathrm{j}=1,2 \ldots . \mathrm{n}=$ Number of markets

qi0=Total exports by the focus country of commodity $i$, in the initial period

qi1=Total exports by the focus country of commodity $i$, in the terminal period

\section{Period of analysis}

The study focuses on to analyze the competitiveness of Indian oilseeds specially groundnut (HS code 1202). For the purpose this study uses primarily various methods of RCA and finally CONSTANT MARKET SHARE. The time period use for RCA(Revealed Comparative Advantage) is from 2008 to 2017, whereas to apply CONSTANT MARKET SHARE two periods have been used 2000-2006 and 2007-17 because of WORLD TRADE ORGANIZATION agreement which start impacting from 2007.

Constant market share calculations

Table II: CONSTANT MARKET SHARE Calculations

\section{RESULTS}

The analysis employs Revealed Comparative Advantage Indices as indicated in the following table. The RCA introduced by Bela Balassa, known as Balassa Index. RCA index value greater than 1 indicates that country has comparative advantage in the export of product in the world market and the RCA index value lesser than 1 shows that country has comparative disadvantage in the world market. In 1991, Thomas Lachlan Vollrath has proposed three alternative RCA indices to measure the revealed comparative advantage of nation; the Relative trade advantage (RTA), the logarithm of the relative export advantage (ln RXA) and the Vollrath measure of revealed competitiveness (RC). [1][2][6] To overcome the problem of upward-biased RCA index values, Laursen (1998) adjusts the RCA index to make it symmetric, such that the adjusted index values are between -1 and +1 . Positive (negative) values of following RC's show a competitive advantage (disadvantage) in exporting product in the world market.

\section{Table I: RCA Calculations}

The above table with various methodologies of Relative Competitiveness indicates that India has the competitive advantage in exporting groundnuts from year 2008 to 2017.

\begin{tabular}{|l|l|l|l|l|l|l|}
\hline Year & RCA(or RXA) & RMA & RTA & ln RXA & In RMA & RC \\
\hline & & & & & & \\
\hline 2008 & 16.23835 & 0.000277 & 16.23808 & 2.787376 & -8.19119 & 10.97857 \\
\hline 2009 & 11.02466 & 0.000815 & 11.02384 & 2.400134 & -7.11227 & 9.512401 \\
\hline 2010 & 17.09855 & 0.005449 & 17.0931 & 2.838994 & -5.21228 & 8.051273 \\
\hline 2011 & 22.29136 & 0.007024 & 22.28433 & 3.104199 & -4.95845 & 8.062651 \\
\hline 2012 & 20.73645 & 0.000694 & 20.73575 & 3.031893 & -7.27275 & 10.30464 \\
\hline 2013 & 11.02277 & 0.000885 & 11.02188 & 2.399963 & -7.03029 & 9.430257 \\
\hline 2014 & 17.31902 & 0.00034 & 17.31868 & 2.851806 & -7.98622 & 10.83803 \\
\hline 2015 & 17.36536 & 0.001306 & 17.36405 & 2.854477 & -6.64104 & 9.495517 \\
\hline 2016 & 16.19041 & 0.001084 & 16.18932 & 2.784419 & -6.82666 & 9.611076 \\
\hline 2017 & 14.55995 & 0.020973 & 14.53897 & 2.678274 & -3.86454 & 6.542812 \\
\hline Mean & 16.384688 & 0.003885 & 16.3808 & 2.773154 & -6.50957 & 9.282723 \\
\hline
\end{tabular}

The mean values of all the RC's are above $>1$ (other than 0.003885 ) and thus India has a comparative advantage in export of oilseeds specially groundnuts.

Further to analyze the competitiveness from the changes in the export performance of a country the Constant Market Share (CMS) model is widely used. The CMS analysis can be applied as a descriptive or diagnostic tool (Ahmadi Esfahani, 2006). This model decomposed into four structural components that could cause changes in the country's export share overtime. 
International Journal of Innovative Technology and Exploring Engineering (IJITEE) ISSN: 2278-3075, Volume-8, Issue-9S, July 2019

\begin{tabular}{|c|c|c|c|c|c|c|c|c|}
\hline Country & $\begin{array}{c}\text { AVERAGE } \\
(2001-2006) \text { qo }\end{array}$ & $\begin{array}{l}\text { AVERAGE } \\
(2007-17) \mathrm{q} 1\end{array}$ & $\mathrm{q} 1-\mathrm{q} 0$ & $\mathrm{r}$ & rq0 & r1 & rlq0 & $\mathrm{r} 1 \mathrm{q} 0$ - rq0 \\
\hline Albania & 0 & 82.81818182 & 82.81818 & 1.898807 & 0 & 2.002039 & 0 & 0 \\
\hline Algeria & 370 & 7681.454545 & 7311.455 & 1.898807 & 702.5588 & 2.002039 & 740.7544 & 38.19564 \\
\hline Angola & 0 & 56.72727273 & 56.72727 & 1.898807 & 0 & 2.002039 & 0 & 0 \\
\hline Armenia & 0 & 18.90909091 & 18.90909 & 1.898807 & 0 & 2.002039 & 0 & 0 \\
\hline Australia & 10.5 & 24.45454545 & 13.95455 & 1.898807 & 19.93748 & 2.002039 & 21.02141 & 1.08393 \\
\hline Austria & 0.333333333 & 1.545454545 & 1.212121 & 1.898807 & 0.632936 & 2.002039 & 0.667346 & 0.03441 \\
\hline Azerbaijan & 0 & 35.63636364 & 35.63636 & 1.898807 & 0 & 2.002039 & 0 & 0 \\
\hline Bahrain & 11.16666667 & 105.6363636 & 94.4697 & 1.898807 & 21.20335 & 2.002039 & 22.3561 & 1.152751 \\
\hline Bangladesh & 42.83333333 & 370.8181818 & 327.9848 & 1.898807 & 81.33225 & 2.002039 & 85.754 & 4.421748 \\
\hline Belarus & 4.6666666667 & 192 & 187.3333 & 1.898807 & 8.861102 & 2.002039 & 9.342848 & 0.481747 \\
\hline Belgium & 339.8333333 & 307.9090909 & -31.9242 & 1.898807 & 645.2781 & 2.002039 & 680.3596 & 35.08149 \\
\hline Bhutan & 0 & 6.090909091 & 6.090909 & 1.898807 & 0 & 2.002039 & 0 & 0 \\
\hline $\begin{array}{l}\text { Bosnia and } \\
\text { Herzegovina }\end{array}$ & 0 & 56.45454545 & 56.45455 & 1.898807 & 0 & 2.002039 & 0 & 0 \\
\hline Botswana & 0 & 0.181818182 & 0.181818 & 1.898807 & 0 & 2.002039 & 0 & 0 \\
\hline Brazil & 1.166666667 & 13.63636364 & 12.4697 & 1.898807 & 2.215275 & 2.002039 & 2.335712 & 0.120437 \\
\hline Brunei Darussalam & 96 & 454.0909091 & 358.0909 & 1.898807 & 182.2855 & 2.002039 & 192.1957 & 9.91022 \\
\hline Bulgaria & 104.1666667 & 156.1818182 & 52.01515 & 1.898807 & 197.7924 & 2.002039 & 208.5457 & 10.75328 \\
\hline Cabo Verde & 0 & 10.18181818 & 10.18182 & 1.898807 & 0 & 2.002039 & 0 & 0 \\
\hline Cambodia & 0 & 633.7272727 & 633.7273 & 1.898807 & 0 & 2.002039 & 0 & 0 \\
\hline Canada & 487 & 593.1818182 & 106.1818 & 1.898807 & 924.7192 & 2.002039 & 974.993 & 50.27372 \\
\hline China & 74 & 14679.27273 & 14605.27 & 1.898807 & 140.5118 & 2.002039 & 148.1509 & 7.639128 \\
\hline Colombia & 0 & 188.8181818 & 188.8182 & 1.898807 & 0 & 2.002039 & 0 & 0 \\
\hline Costa Rica & 0 & 3.272727273 & 3.272727 & 1.898807 & 0 & 2.002039 & 0 & 0 \\
\hline Croatia & 0 & 289.9090909 & 289.9091 & 1.898807 & 0 & 2.002039 & 0 & 0 \\
\hline Cyprus & 1.5 & 1.181818182 & -0.31818 & 1.898807 & 2.848211 & 2.002039 & 3.003058 & 0.154847 \\
\hline Czech Republic & 12.16666667 & 0 & -12.1667 & 1.898807 & 23.10216 & 2.002039 & 24.35814 & 1.255983 \\
\hline Denmark & 5.333333333 & 0 & -5.33333 & 1.898807 & 10.12697 & 2.002039 & 10.67754 & 0.550568 \\
\hline $\begin{array}{l}\text { Dominican } \\
\text { Republic }\end{array}$ & 0 & 4.090909091 & 4.090909 & 1.898807 & 0 & 2.002039 & 0 & 0 \\
\hline Ecuador & 0 & 91.27272727 & 91.27273 & 1.898807 & 0 & 2.002039 & 0 & 0 \\
\hline Egypt & 320.3333333 & 2017.181818 & 1696.848 & 1.898807 & 608.2513 & 2.002039 & 641.3198 & 33.06848 \\
\hline Estonia & 50.16666667 & 286.3636364 & 236.197 & 1.898807 & 95.25684 & 2.002039 & 100.4356 & 5.178778 \\
\hline Ethiopia & 0 & 215.4545455 & 215.4545 & 1.898807 & 0 & 2.002039 & 0 & 0 \\
\hline Fiji & 0.666666667 & 0.363636364 & -0.30303 & 1.898807 & 1.265872 & 2.002039 & 1.334693 & 0.068821 \\
\hline Finland & 0 & 13.27272727 & 13.27273 & 1.898807 & 0 & 2.002039 & 0 & 0 \\
\hline France & 10.16666667 & 5.909090909 & -4.25758 & 1.898807 & 19.30454 & 2.002039 & 20.35406 & 1.04952 \\
\hline Georgia & 7.166666667 & 706.6363636 & 699.4697 & 1.898807 & 13.60812 & 2.002039 & 14.34795 & 0.739825 \\
\hline Germany & 494.1666667 & 805.8181818 & 311.6515 & 1.898807 & 938.3274 & 2.002039 & 989.3409 & 51.01355 \\
\hline Greece & 5.166666667 & 299.0909091 & 293.9242 & 1.898807 & 9.810505 & 2.002039 & 10.34387 & 0.533363 \\
\hline Grenada & 0 & 8.181818182 & 8.181818 & 1.898807 & 0 & 2.002039 & 0 & 0 \\
\hline Guyana & 0 & 0.636363636 & 0.636364 & 1.898807 & 0 & 2.002039 & 0 & 0 \\
\hline Hong Kong, China & 51.666666667 & 4347.818182 & 4296.152 & 1.898807 & 98.10505 & 2.002039 & 103.4387 & 5.333626 \\
\hline Hungary & 43 & 2.545454545 & -40.4545 & 1.898807 & 81.64872 & 2.002039 & 86.08767 & 4.438953 \\
\hline
\end{tabular}


Export Competitiveness of Indian Oilseeds: The Method of CMS with Special Reference to Groundnut

\begin{tabular}{|c|c|c|c|c|c|c|c|c|}
\hline Iceland & 17.166666667 & 0 & -17.1667 & 1.898807 & 32.5962 & 2.002039 & 34.36834 & 1.77214 \\
\hline Indonesia & 43958.16667 & 193161.7273 & 149203.6 & 1.898807 & 83468.1 & 2.002039 & 88005.96 & 4537.866 \\
\hline $\begin{array}{l}\text { Iran, Islamic } \\
\text { Republic of }\end{array}$ & 18.33333333 & 4152.272727 & 4133.939 & 1.898807 & 34.81147 & 2.002039 & 36.70405 & 1.892577 \\
\hline Ireland & 57.33333333 & 243.7272727 & 186.3939 & 1.898807 & 108.865 & 2.002039 & 114.7836 & 5.918604 \\
\hline Israel & 8.166666667 & 589.3636364 & 581.197 & 1.898807 & 15.50693 & 2.002039 & 16.34998 & 0.843057 \\
\hline Italy & 720.8333333 & 23.45454545 & -697.379 & 1.898807 & 1368.724 & 2.002039 & 1443.136 & 74.41268 \\
\hline Jamaica & 0 & 0.727272727 & 0.727273 & 1.898807 & 0 & 2.002039 & 0 & 0 \\
\hline Japan & 103.5 & 431.6363636 & 328.1364 & 1.898807 & 196.5266 & 2.002039 & 207.211 & 10.68446 \\
\hline Jordan & 71.666666667 & 382 & 310.3333 & 1.898807 & 136.0812 & 2.002039 & 143.4795 & 7.398255 \\
\hline Kazakhstan & 0 & 113.8181818 & 113.8182 & 1.898807 & 0 & 2.002039 & 0 & 0 \\
\hline Kenya & 2.166666667 & 15.54545455 & 13.37879 & 1.898807 & 4.114083 & 2.002039 & 4.337751 & 0.223668 \\
\hline Korea, Republic of & 1.833333333 & 13.45454545 & 11.62121 & 1.898807 & 3.481147 & 2.002039 & 3.670405 & 0.189258 \\
\hline Kuwait & 130.1666667 & 762.9090909 & 632.7424 & 1.898807 & 247.1614 & 2.002039 & 260.5987 & 13.4373 \\
\hline Latvia & 19 & 134.9090909 & 115.9091 & 1.898807 & 36.07734 & 2.002039 & 38.03874 & 1.961398 \\
\hline Lebanon & 0 & 229 & 229 & 1.898807 & 0 & 2.002039 & 0 & 0 \\
\hline Lithuania & 17.5 & 283 & 265.5 & 1.898807 & 33.22913 & 2.002039 & 35.03568 & 1.806551 \\
\hline $\begin{array}{l}\text { Macedonia, The } \\
\text { Former Yugoslav } \\
\text { Republic of }\end{array}$ & 8 & 68.18181818 & 60.18182 & 1.898807 & 15.19046 & 2.002039 & 16.01631 & 0.825852 \\
\hline Malawi & 0 & 1.727272727 & 1.727273 & 1.898807 & 0 & 2.002039 & 0 & 0 \\
\hline Malaysia & 19335.16667 & 65575.90909 & 46240.74 & 1.898807 & 36713.76 & 2.002039 & 38709.76 & 1995.998 \\
\hline Maldives & 4.6666666667 & 4.363636364 & -0.30303 & 1.898807 & 8.861102 & 2.002039 & 9.342848 & 0.481747 \\
\hline Mali & 2.166666667 & 0 & -2.16667 & 1.898807 & 4.114083 & 2.002039 & 4.337751 & 0.223668 \\
\hline Malta & 7.5 & 0 & -7.5 & 1.898807 & 14.24106 & 2.002039 & 15.01529 & 0.774236 \\
\hline Mauritius & 221.1666667 & 351.1818182 & 130.0152 & 1.898807 & 419.9529 & 2.002039 & 442.7843 & 22.83136 \\
\hline Mexico & 299.3333333 & 7074.181818 & 6774.848 & 1.898807 & 568.3764 & 2.002039 & 599.277 & 30.90062 \\
\hline $\begin{array}{l}\text { Moldova, Republic } \\
\text { of }\end{array}$ & 0 & 29.72727273 & 29.72727 & 1.898807 & 0 & 2.002039 & 0 & 0 \\
\hline Montenegro & 0 & 48.18181818 & 48.18182 & 1.898807 & 0 & 2.002039 & 0 & 0 \\
\hline Morocco & 94.66666667 & 5.363636364 & -89.303 & 1.898807 & 179.7538 & 2.002039 & 189.5264 & 9.772579 \\
\hline Mozambique & 0 & 19.54545455 & 19.54545 & 1.898807 & 0 & 2.002039 & 0 & 0 \\
\hline Nepal & 281.5 & 1358.090909 & 1076.591 & 1.898807 & 534.5143 & 2.002039 & 563.574 & 29.05966 \\
\hline Netherlands & 1679.833333 & 3014.090909 & 1334.258 & 1.898807 & 3189.68 & 2.002039 & 3363.092 & 173.4117 \\
\hline $\begin{array}{l}\text { Netherlands } \\
\text { Antilles }\end{array}$ & 4.5 & 0 & -4.5 & 1.898807 & 8.544634 & 2.002039 & 9.009175 & 0.464542 \\
\hline New Zealand & 0.1666666667 & 12.63636364 & 12.4697 & 1.898807 & 0.316468 & 2.002039 & 0.333673 & 0.017205 \\
\hline Niger & 1.5 & 0 & -1.5 & 1.898807 & 2.848211 & 2.002039 & 3.003058 & 0.154847 \\
\hline Nigeria & 0 & 0.818181818 & 0.818182 & 1.898807 & 0 & 2.002039 & 0 & 0 \\
\hline Norway & 4.6666666667 & 8.272727273 & 3.606061 & 1.898807 & 8.861102 & 2.002039 & 9.342848 & 0.481747 \\
\hline Oman & 10 & 363.3636364 & 353.3636 & 1.898807 & 18.98807 & 2.002039 & 20.02039 & 1.032315 \\
\hline Pakistan & 466 & 15289.72727 & 14823.73 & 1.898807 & 884.8443 & 2.002039 & 932.9502 & 48.10586 \\
\hline Philippines & 8423.5 & 55389 & 46965.5 & 1.898807 & 15994.6 & 2.002039 & 16864.18 & 869.5702 \\
\hline Poland & 515.6666667 & 11.54545455 & -504.121 & 1.898807 & 979.1517 & 2.002039 & 1032.385 & 53.23302 \\
\hline Portugal & 0.1666666667 & 0 & -0.16667 & 1.898807 & 0.316468 & 2.002039 & 0.333673 & 0.017205 \\
\hline Qatar & 22 & 232.7272727 & 210.7273 & 1.898807 & 41.77376 & 2.002039 & 44.04486 & 2.271092 \\
\hline Romania & 62.83333333 & 4.363636364 & -58.4697 & 1.898807 & 119.3084 & 2.002039 & 125.7948 & 6.486377 \\
\hline Russian Federation & 293.1666667 & 8452.272727 & 8159.106 & 1.898807 & 556.6671 & 2.002039 & 586.9311 & 30.26402 \\
\hline
\end{tabular}




\begin{tabular}{|c|c|c|c|c|c|c|c|c|}
\hline Saudi Arabia & 675.5 & 2342 & 1666.5 & 1.898807 & 1282.644 & 2.002039 & 1352.377 & 69.73285 \\
\hline Senegal & 0 & 0.181818182 & 0.181818 & 1.898807 & 0 & 2.002039 & 0 & 0 \\
\hline Serbia & 0 & 335.6363636 & 335.6364 & 1.898807 & 0 & 2.002039 & 0 & 0 \\
\hline Seychelles & 2 & 7.636363636 & 5.636364 & 1.898807 & 3.797615 & 2.002039 & 4.004078 & 0.206463 \\
\hline Singapore & 3018.833333 & 6580 & 3561.167 & 1.898807 & 5732.183 & 2.002039 & 6043.822 & 311.6386 \\
\hline Slovakia & 24 & 4 & -20 & 1.898807 & 45.57138 & 2.002039 & 48.04893 & 2.477555 \\
\hline Slovenia & 10.666666667 & 6.363636364 & -4.30303 & 1.898807 & 20.25395 & 2.002039 & 21.35508 & 1.101136 \\
\hline Somalia & 10.83333333 & 0 & -10.8333 & 1.898807 & 20.57041 & 2.002039 & 21.68876 & 1.118341 \\
\hline South Africa & 1090 & 2573.818182 & 1483.818 & 1.898807 & 2069.7 & 2.002039 & 2182.222 & 112.5223 \\
\hline Spain & 15.83333333 & 17.54545455 & 1.712121 & 1.898807 & 30.06445 & 2.002039 & 31.69895 & 1.634498 \\
\hline Sri Lanka & 1066.333333 & 2508.272727 & 1441.939 & 1.898807 & 2024.762 & 2.002039 & 2134.841 & 110.0792 \\
\hline Suriname & 0 & 12.54545455 & 12.54545 & 1.898807 & 0 & 2.002039 & 0 & 0 \\
\hline Swaziland & 0 & 31.72727273 & 31.72727 & 1.898807 & 0 & 2.002039 & 0 & 0 \\
\hline Sweden & 0 & 13.18181818 & 13.18182 & 1.898807 & 0 & 2.002039 & 0 & 0 \\
\hline Switzerland & 0 & 0.454545455 & 0.454545 & 1.898807 & 0 & 2.002039 & 0 & 0 \\
\hline $\begin{array}{l}\text { Syrian Arab } \\
\text { Republic }\end{array}$ & 4.5 & 338.8181818 & 334.3182 & 1.898807 & 8.544634 & 2.002039 & 9.009175 & 0.464542 \\
\hline Taipei, Chinese & 546.5 & 2938.818182 & 2392.318 & 1.898807 & 1037.698 & 2.002039 & 1094.114 & 56.41599 \\
\hline Thailand & 100 & 27485.45455 & 27385.45 & 1.898807 & 189.8807 & 2.002039 & 200.2039 & 10.32315 \\
\hline $\begin{array}{l}\text { Trinidad and } \\
\text { Tobago }\end{array}$ & 0 & 13.45454545 & 13.45455 & 1.898807 & 0 & 2.002039 & 0 & 0 \\
\hline Tunisia & 0 & 49.27272727 & 49.27273 & 1.898807 & 0 & 2.002039 & 0 & 0 \\
\hline Turkey & 74.33333333 & 1179.454545 & 1105.121 & 1.898807 & 141.1447 & 2.002039 & 148.8182 & 7.673539 \\
\hline Turkmenistan & 0 & 33.27272727 & 33.27273 & 1.898807 & 0 & 2.002039 & 0 & 0 \\
\hline Uganda & 1.333333333 & 0 & -1.33333 & 1.898807 & 2.531743 & 2.002039 & 2.669385 & 0.137642 \\
\hline Ukraine & 1992.166667 & 11811.18182 & 9819.015 & 1.898807 & 3782.741 & 2.002039 & 3988.395 & 205.6543 \\
\hline $\begin{array}{l}\text { United Arab } \\
\text { Emirates }\end{array}$ & 1621.666667 & 8025.545455 & 6403.879 & 1.898807 & 3079.233 & 2.002039 & 3246.64 & 167.407 \\
\hline United Kingdom & 4698 & 4906.545455 & 208.5455 & 1.898807 & 8920.598 & 2.002039 & 9405.579 & 484.9814 \\
\hline $\begin{array}{l}\text { United States of } \\
\text { America }\end{array}$ & 3336.833333 & 281.0909091 & -3055.74 & 1.898807 & 6336.004 & 2.002039 & 6680.47 & 344.4662 \\
\hline Uruguay & 0 & 0.272727273 & 0.272727 & 1.898807 & 0 & 2.002039 & 0 & 0 \\
\hline Viet Nam & 112.3333333 & 89871.09091 & 89758.76 & 1.898807 & 213.2994 & 2.002039 & 224.8957 & 11.59633 \\
\hline \multirow[t]{5}{*}{ Yemen } & 174.8333333 & 3812.818182 & 3637.985 & 1.898807 & 331.9748 & 2.002039 & 350.0231 & 18.0483 \\
\hline & 97983.66667 & 557802 & 459818.3 & 218.3629 & 186052.1 & 230.2345 & 196167.1 & 10115 \\
\hline & & & & & 459818.3 & & & \\
\hline & & & 100 & & 40.46209 & & & 2.199781 \\
\hline & & & Total Effect & & WTE & & & CCE \\
\hline
\end{tabular}

Table III : Competitiveness Effect

\begin{tabular}{|l|l|l|}
\hline \multicolumn{3}{|c|}{ 2000-2006 compared to 2007-2017 } \\
\hline Decomposition & Value(in USD) & $\%$ \\
\hline Change in Exports & 459818.3333 & 100 \\
\hline World Trade Effect & 186052.1198 & 40.46209 \\
\hline $\begin{array}{l}\text { Market Distribution } \\
\text { Effect }\end{array}$ & 10114.99729 & 2.199781 \\
\hline $\begin{array}{l}\text { Commodity } \\
\text { Composition Effect }\end{array}$ & -520647.5087 & -113.229 \\
\hline Competitiveness Effect & 784298.725 & 170.5671 \\
\hline
\end{tabular}

Above table is formed to examine the results of Constant Market Share (CONSTANT MARKET SHARE) on the basis of the export share of India in the total world export for the four Groundnut oilseeds during the period I (2000-06) and period II (2007-17). The above table decompose the results of CONSTANT MARKET SHARE into four structural components (Change in Total Export)

1. World Trade Effects,

2. Commodity Composition Effect, 
3. Market Distribution Effect and

4. Competitiveness Effect

Table indicates the relative contribution of each of the components of CONSTANT MARKET SHARE

model on the expansion of export of Groundnut (OILseeds) for India for the selected periods. Total export change of India for Groundnut (OILseeds) in value term USD 459818.3333 million for the period I to II. The world trade effect and market distribution effects have positively contributed to the change in the total export of India during the period I(2000-06) to period II (2007-17) with the contribution of $40.46209 \%$ and $2.199781 \%$. The results for World trade effects in the table indicates the increases in the Groundnut (OILseeds) export of India with expansion in the size of world market during the period I to period II. Similarly, the results of market distribution effects exhibit that Indian export of Groundnut (OILseeds) is concerted in the markets where demand is rising faster than world demand. The negative value -113.229 of commodity composition effects suggests that India concentrates on slowly grew markets for Groundnut (OILseeds). During the same period, India gains market share of her export of Groundnut (OILseeds) in the various markets due to its competitiveness in the export of the same product.

\section{CONCLUSION}

The above analyses clearly depicts that India has a competitive advantage in exports for Groundnut (OILSeed). The RCA reveals that over the years from 2008 to 2017 after WORLD TRADE ORGANIZATION india maintained the advantage. Fturther CONSTANT MARKET SHARE reveals that while comparing the periods before and after WORLD TRADE ORGANIZATION India has benefited in the advantage.

\section{REFERENCES}

[1]Balassa, Bela (1977), “'Revealed' Comparative Advantage Revisited: An Analysis of Relative Export Shares of the Industrial Countries, 1953-1971", The Manchester School of Economic \& Social Studies, 1977, vol. 45, issue 4, pp. 327-44.

[2] Verghese SK (1979) Developments in International Competitiveness in India in 1970. Economic and Political Weekly 14: 1718-1726.

[3] Balance, Robert H, Helmut Forstner and Tracy Murray (1987), "Consistency Tests of Alternative Measures of Comparative Advantage", the Review of Economics and Statistics, Vol. 69, No. 1, pp. 157-161.2.

[4]Reddy, B. D. R., Lalith Achoth and B. V. Chenappa Reddy., 1998, Export Competitiveness of Groundnut Empirical Evidence from Karnataka. Astha Vijnana, Vol.15 (3): pp. 263-270.

[5]Bhavani T.A (2001), "Determinants of firm-level export performance: a case study of Indian Textile garments and apparel industry", The Journal of International Trade \& Economic Development.10:1, $65-92$.

[6]Datta, S.K., 2001. How to Judge Global Competitiveness of Indian Agribusiness: Methodological Issues and Lessons for India. In S.K.Datta and S.Y.Deodhar (Eds), Implications of WORLD TRADE ORGANIZATION Agreements for Indian Agriculture. Oxford and IBH Publishing Co.Pvt.Ltd, New Delhi.

[7] Samar Verma (November, 2002) "Export Competitiveness Of Indian Textile And Garment Industry"

[8] Verma S (2002) Export Competitiveness of Indian Textile and Garment Industry Working.Indian Council for Research on International Economic Relations 94

[9]Ranjana Kumar (2005) “Constrains facing Indian agriculture: Need for policy intervention”, Indian journal of agricultural economics, Vol. 60, No. 01, Jan -March.

[10] RS Deshpande (March, 2005) "Karnataka Oilseed Production".
[11] Zhang, Xiu-ling and Liu, M., 2008. Experimental study on the international competition power of China's peanut industry. Journal of Henan Agricultural Sciences, 11.

[12] Bhatt PR (2010) China's Competitiveness in World Economy Foreign Trade 44: 19-41.

[13] Jiang Y, Zhang Q, Chai J (2010) The Empirical Research of the Competitiveness based on the Informationization of China's Textile \& Clothing Industry. The Conference on Web Based Business Management.

[14] HailegiorgisBiramoAllaro (2011) "Export Performance of Oilseeds and ITS Determinants in Ethiopia".

[15] Devendra S (2013) Performace of Indian Textile and Clothing Industry in the United States Market A Post ATC Analysis. Journal of Research in Commerce \& Management 2: 64-76.

[16] Sharma SK, Bugalya K (2014) Competitiveness of Indian agriculture sector a case study of cotton crop Procedia - Social and Behavioral Sciences 133: 320-335.

[17] Dr. N C Pahariya (2014) "Impact Assessment of Trade Liberalisation in Oilseeds Sector : Rajasthan".

[18] Akmal, N., W. Akhtar, H. Shah, M. A. Niazi and T. Saleem, 2014. The structure and competitiveness of Pakistan's Basmati Rice exports. Asian Journal of Agriculture and Rural Development, 4 (4): 304-312.

[19] Sunil Kumar Niranjan (2016) "WORLD TRADE ORGANIZATION Agreement on Indian Oilseed Agriculture".

[20] Cann O (2016) what is competitiveness? World Economic Forum.

\section{AUTHORS PROFILE}

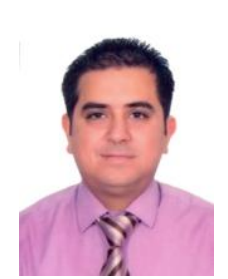

Anudeep Arora was honored with $\mathbf{2 5}^{\text {th }}$ Prestigious Dr Sarvepalli Radhakrishnan Smriti National Media and Teacher Network Award at Hansraj College Delhi University. He received this award from Ram Niwas Goyal, speaker of Delhi Vidhan Sabha and RajInder Pal Gautam, Minister of water, social welfare, art and culture, GNCT Delhi.

He has facilitated various conferences, programs and seminars on Digital Media Marketing, Leadership and other topics for Corporate Professionals, faculties and students. He has been associated as an Assistant professor with Kamal Institute of Higher education and Advance Technology (G.G.S.IPU). He has taught subjects like International Business Management, Export and import documentation, International Marketing, Entrepreneurship Development, International Trade Operations, Market Research, Production and Operation Management, Family Business Management, Indian Economy, Foreign Trade Policy, Brand Management in MBA and other post graduate programs. He has prepared students for various cultural and literary competitions. More than Twenty five research papers of Anudeep Arora have been published in well-regarded national and international journals. He is UGC NET Qualified and did his Masters in International Business from Amity University and currently pursuing $\mathrm{Ph} . \mathrm{D}$ in Management from Amity University. He was awarded the silver medal for standing second in academics in entire university while doing graduation

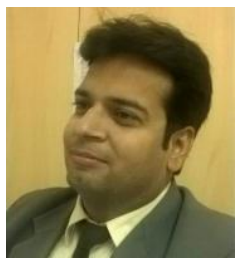

Durgesh Batra, BSc, (Rajasthan University), BT(Computing),(Thompson River University, Canada), MSc(statistics),(Rajasthan University), MBA(Mkt \& Fin)( Rajasthan University), ADSE(Hons)(4 year diploma in computer sciences from APtech Computer Ed.), $\mathrm{PhD}$.( Rajasthan University). He has an experience of $14+$ years including 1.5 years in projects with different private and government organizations and $12+$ in Teaching with reputed institutes and Universities. Training and development workshops conducted: Several Workshops conducted with CA institute/ Geographical Institutes on Communication skills, Banks for Basic Computers etc. Consultancy: 3 months on ERP to SamScreen US. And 1 year to RUIFDCO (SLNA for Ministry of Housing and Poverty Alleviation. 